Nama : Adhe Roy Gumilang

NRP :130118069

Mata Kuliah : Strategi International

\title{
Strategies Used by Multinational Companies
}

Ada berbagai macam jenis strategi penetrasi yang dilakukan oleh perusahaan multi nasional, antara lain wholly owned subsidiary, join venture, licence agreement, subcontracting, and outsourcing. Jelaskan masing-masing kelebihan dan kelemahan masing-masing strategi tersebut.

\section{Wholly Owned Subsidiary}

Wholly owned subsidiary adalah perusahaan yang saham biasa $100 \%$ dimiliki oleh perusahaan lain, yaitu perusahaan induk. Sedangkan suatu perusahaan dapat menjadi wholly owned subsidiary melalui akuisisi oleh perusahaan induk atau telah dipisahkan dari perusahaan induk, maka anak perusahaan biasa adalah 51\% sampai 99\% dimiliki oleh perusahaan induk.

Ketika biaya dan risiko yang lebih rendah diinginkan - atau ketika tidak mungkin untuk memperoleh kendali penuh atau mayoritas - perusahaan induk mungkin memperkenalkan perusahaan afiliasi, rekanan, atau rekanan di mana ia akan memiliki saham minoritas.

- Kelebihan dan Kelemahan

Meskipun perusahaan induk memiliki kendali operasional dan strategis atas wholly owned subsidiary, kendali keseluruhan biasanya kurang untuk anak perusahaan yang diakuisisi dengan riwayat operasi yang kuat di luar negeri. Ketika perusahaan mempekerjakan stafnya sendiri untuk mengelola anak perusahaan, membentuk prosedur operasi umum jauh lebih mudah daripada saat mengambil alih perusahaan dengan kepemimpinan yang mapan. 
Selain itu, perusahaan induk dapat menerapkan akses datanya sendiri dan arahan keamanan untuk anak perusahaan sebagai metode untuk mengurangi risiko kehilangan kekayaan intelektual kepada perusahaan lain. Demikian pula, menggunakan sistem keuangan yang serupa, berbagi layanan administratif, dan membuat program pemasaran serupa membantu mengurangi biaya bagi kedua perusahaan, dan perusahaan induk mengarahkan bagaimana aset anak perusahaan yang dimiliki sepenuhnya diinvestasikan.

Namun, mendirikan wholly owned subsidiary dapat mengakibatkan perusahaan induk membayar terlalu banyak untuk aset, terutama jika perusahaan lain mengajukan penawaran pada bisnis yang sama. Selain itu, menjalin hubungan dengan vendor dan klien lokal sering kali membutuhkan waktu, yang dapat menghambat operasi perusahaan; perbedaan budaya dapat menjadi masalah saat mempekerjakan staf untuk anak perusahaan di luar negeri.

Perusahaan induk juga menanggung semua risiko memiliki anak perusahaan, dan risiko tersebut dapat meningkat bila undang-undang setempat berbeda secara signifikan dari undang-undang di negara perusahaan induk.

\section{Joint Venture}

Perjanjian Patungan atau Joint Venture adalah bentuk persekutuan yang menekankan kerjasama lebih daripada untuk suatu yang sementara sifatnya. Perusaaan patungan terbentuk ketika dua pihak atau lebih, baik secara pribadi maupun perusahaan bermaksud menjadi partner satu sama lainnya untuk suatu kegiatan dan mengatur secara bersama suatu perusahaan baru yang sahamsahamnya dimiliki secara Bersama

- Kelebihan dan Kelemahan

Kedudukan joint venture dalam penanaman modal di Indonesia adalah sebagai salah satu cara penanaman modal asing yang dilakukan oleh investor asing dalam menanamkan modal di Indonesia. Keberadaan perusahaan joint venture dalam penanaman modal mempunyai arti dan manfaat yang sangat besar bagi penanam modal dalam negeri atau 
nasional maupun penanaman modal asing yakni sebagai pembatasan resiko dimana dalam melakukan suatu kegiatan sudah barang pasti penuh resiko seperti kesalahan dalam memilih atau menentukan mitra maka akan meningkatkan resiko politik. Dengan membentuk kerja sama maka resiko tersebut dapat disebarkan kepada peserta-peserta dan sebagai pembiayaan, dimana kerja sama usaha mendayagunakan modal dapat dilakukan dengan sederhana dengan menyatukan modal yang dibutuhkan.

\section{Licence Agreement}

Perjanjian Lisensi adalah kontrak hukum antara dua pihak, yang dikenal sebagai pemberi lisensi dan penerima lisensi. Dalam perjanjian lisensi yang khas, pemberi lisensi memberikan hak kepada pemegang lisensi untuk memproduksi dan menjual barang, menerapkan nama merek atau merek dagang, atau menggunakan teknologi yang dipatenkan milik pemberi lisensi. Sebagai gantinya, penerima lisensi biasanya tunduk pada serangkaian ketentuan terkait penggunaan properti pemberi lisensi dan setuju untuk melakukan pembayaran yang dikenal sebagai royalti.

- Kelebihan dan Kelemahan

Perjanjian lisensi merk yang paling banyak dilakukan adalah terhadap merk terkenal, hal ini karen a merk terkenal memiliki beberapa kelebihan. Suatu merk yang menjadi merk terkenal menjadi andalan pengusaha dalam memenangkan persaingan yang semakin ketat. Fakta itu menyebabkan merkmerk terkenal menjadi incaran pemalsuan dan penyalahgunaan bagi pihakpihak yang beritikad buruk. Sebagai salah satu kontrak bisnis, perjanj ian lisensi merk didalamnya terkandung beberapa prinsip hukum kontrak yang menjadi pijakan bagi para pihak untuk membuat dan melaksanakannya. Prinsip-prinsip hukum kontrak terse but terdapat dalam BW. Prinsip-prinsip hukum kontrak tersebut merupakan dasar yang harus dipatuhi oleh para pihak, agar perjanjian lisensi yang dibuat tidak merugikan salah satu pihak dan dapat dilaksanakan secara adil.

\section{Subcontracting}

Subkontraktor merupakan kontraktor spesialisasi yang mengerjakan pekerjaan konstruksi tertentu, terkadang berfungsi sebagai agen dari sistem produksi perusahaan konstruksi untuk menyuplai material, tenaga kerja, peralatan, suku cadang bahkan desain Matthew dan Kumaraswamy, 2000). 
Subkontraktor adalah perusahaan konstruksi yang melakukan kontrak dengan kontraktor utama untuk melakukan beberapa item pekerjaan tertentu, bentuk kontrak yang dilakukan (subcontracting) akan terpisah dengan kontrak utama dan akan diselesaikan sebelum masa kontrak utama selesai. Sehingga subcontracting merupakan suatu perikatan kontrak atau legalitas dari sebuah kerjasama pengerjaan proyek konstruksi. Pada umumnya subcontracting dilakukan oleh kontraktor utama dengan menyerahkan pekerjaan minor atau khusus kepada subkontraktor, kecenderungan ini akan terus dilakukan bersamaan dengan semakin besarnya nilai dan volume pekerjaan utama.

\section{- Kelebihan dan Kekurangan}

Dalam skala produktifitas ekonomis suatu proyek, penerapan spesialisasi melalui subcontracting dapat menjadikan suatu pekerjaan konstruksi menjadi lebih ekonomis. Pekerjaan yang di luar kemampuan kontraktor utama dan membutuhkan sumber daya yang besar dan mahal maka dapat diserahkan pada spesialisasi/subkontraktor. Sehingga pelibatan tersebut dapat ditempuh dengan penguatan koordinasi diantara pihak yang melakukan kontrak pada lokasi dan konstruksi yang sama (Yik dan Lai, 2006).

Walau dalam pelaksanaannya banyak dirasakan manfaat dari pola partnering berupa perikatan subcontracting, terdapat pula beberapa hal kondisi yang dapat menjadi persoalan apabila tidak dikelola dengan baik. Konsekuensi yang paling mungkin muncul adalah dengan timbulnya ketegangan (strain) dan hubungan yang kurang cair (adversarial) diantara kontraktor dan subkontraktor (Hinze dan Tracey, 1994; Dainty et al., 2001)

\section{Outsourcing}

Outsourcing (Alih Daya) dikenal sebagai penyediaan jasa tenaga kerja seperti yang diatur pada pasal 64, 65 dan 66. Dalam dunia Psikologi Industri, tercatat karyawan outsourcing adalah karyawan kontrak yang dipasok dari sebuah perusahaan penyedia jasa tenaga outsourcing. Awalnya, perusahaan outsourcing menyediakan jenis pekerjaan yang tidak berhubungan langsung dengan bisnis inti perusahaan dan tidak mempedulikan jenjang karier. Seperti operator telepon, call centre, petugas satpam dan tenaga pembersih atau cleaning service. Namun saat ini, penggunaan outsourcing semakin meluas ke berbagai lini kegiatan perusahaan.

- Kelebihan dan Kelemahan 
Menggunakan outsourcing dapat menghemat anggaran untuk melakukan pelatihan terhadap karyawan baru karena mereka memiliki keahlian yang spesifik, dan outsourcing memiliki kekurangan informasi perusahaan yang rentan bocor, kontrak yang singkat dan ketergantngan pada tenaga kerja outsourcing.

Dalam kasus industri alat-alat medis, ada beberapa strategi yang cukup dominan dengan berbagai modifikasinya. Strategi apa yang paling sering digunakan oleh perusahaan multinasional untuk industri tersebut? (lihat Pratono \& Ratih, 2019).

\section{Wholly owned subsidiary in Medhical industry}

Pemerintah Indonesia mendorong perusahaan multinasional untuk berinvestasi dalam produksi perangkat medis kesehatan di Indonesia, yang dapat membentuk sebuah kolaborasi berbasis ekuitas atau merger dan strategi akuisisi (Pratono \& Ratih, 2019). Kolaborasi berbasis ekuitas dan strategi akuisisi adalah salah satu dari strategi aliansi. Strategi aliansi menawarkan alternatif untuk perusahaan, dimana mereka bisa bergabung dengan perusahaan-perusahaan lain dalam mengejar peluang yang seharusnya berada di luar kemampuan perusahaan saat ini. Pada intinya, aliansi memungkinkan mitra perusahaan untuk kreatif menggabungkan sumber daya dalam pembentukan keunggulan kompetitif bersama (Teng \& Das, 2008).

Di Indonesia, itu adalah wajib bagi manufaktur perangkat medis asing mengekspor produk mereka ke Indonesia untuk mematuhi peraturan yang berlaku. Peraturan ini mewajibkan produsen atau pemasok untuk mendaftarkan produk mereka dengan Departemen Kesehatan Indonesia untuk dicatatkan dalam Pendaftaran Alat Kesehatan Indonesia. Ini bisa menjadi cabang perusahaan di Indonesia dari pemilik produk (produsen) atau perusahaan lokal yang diberi wewenang oleh perusahaanperusahaan multinasional untuk mengajukan aplikasi registrasi produk (Pratono \& Ratih, 2019).

Hal ini membuka peluang bagi distributor luar negeri untuk mencoba menjalankan bisnis dengan menggunakan jalan aliansi, dengan mencoba menarik rumah sakit lokal untuk menguasai pasar nasional. Hubungan antara strategi bisnis perusahaan dan seleksi kegiatan aliansi memberikan aspek baru dari analisis untuk aliansi strategis, dan juga berguna untuk perusahaan merencanakan portofolio aliansi sebagai ukuran untuk mencapai tujuan bisnis (Veiga \& Franco, 2015). 
Perusahaan global lebih memilih untuk memimpin integrasi global dalam operasi yang seragam. Aliansi diharapkan dapat mempercepat program pembangunan berdasarkan kemitraan risiko dan pembagian pendapatan (Pratono \& Ratih, 2019).

Kemitraan dengan distributor lokal yang dapat diandalkan adalah perjanjian lisensi Karena ada larangan untuk melakukan penjualan langsung, perjanjian jangka panjang memungkinkan perusahaan multinasional untuk fokus pada strategi pemasaran dan pelayanan serta mengundang distributor tunggal dengan kemampuan yang kuat untuk mengelola seluruh pasar nasional. Pada jenis ini kesepakatan, perusahaan multinasional perlu mengembangkan strategi pemasaran dengan berbagai tingkat pengembangan produk. (Pratono \& Ratih, 2019).

Ketika memanfaatkan aset lisensi perusahaan menggunakan aliansi lisensi, eksekutif mungkin akan tergoda untuk percaya bahwa pengalaman akan membantu perusahaan mengembangkan kompetensi di daerah tersebut. Namun, semua bentuk aliansi termotivasi oleh keinginan perusahaan berpartisipasi untuk mencapai beberapa manfaat (Gammoh \& Voss, 2013).

Dengan perjanjian lisensi membuat distribusi lokal menjadi bisa dikendalikan dan meminimalkan resiko yang ada dan juga dapat mengelola pasar nasional dengan memakai berbagai tingkat produk. Mendirikan usaha aliansi ekuitas (joint venture) untuk mengatasi halangan di daerah lokal. Joint venture menanggapi lingkungan yang dinamis dari perlindungan untuk membuka kebijakan dimana perusahaan multinasional mulai memilih akuisisi atau mode entri hijau, yang memungkinkan mereka untuk mengelola operasi global dengan fokus pada produk teknologi rendah, seperti furnitur rumah sakit dan produk pembuangan (Pratono \& Ratih, 2019).

Joint venture yang mengembangkan budaya kolektivis mampu mengelola mereka konflik kooperatif, dan pendekatan kooperatif ini untuk konflik mempromosikan pembelajaran tim untuk berbagi pengetahuan dan kinerja perusahaan, sedangkan nilai-nilai individualistis menyebabkan kompetitif konflik manajemen dan performa lemah. Dalam kerjasama, mereka percaya tujuan mereka terkait secara positif sehingga sebagai salah satu orang bergerak ke arah pencapaian tujuan, orang lain juga bergerak ke arah mencapai tujuan mereka. Dengan tujuan koperasi, mitra saling membantu sukses (Wong, Wei, \& Wang, 2018).

Joint venture akan dapat membuat perusahaan multinasional akan dapat menyesuaikan dengan lingkungan dan dapat menyesuaikan produknya dengan kebijakan dan kesuaian pasar, dan hal hal ini didukung oleh keinginan perusahaan yang bergerak untuk mencapai tujuannya sehingga dapat mengatasi pasar sehingga akhirnya menguasai pasar dengan jenis aliansi ini. 


\section{Bibliography}

https://www.investopedia.com/terms/w/whollyownedsubsidiary.asp

Erma Rajagukguk, Indonesianisasi Saham, cet. II (Jakarta: Rineka Cipta, 1994), hlm 12

Christian, Glynna K. "Joint Ventures: Understanding licensing issues." The Licensing Journal. October 2005

4 Hukum Online, II Oktober 2009.

Matthew, J. \& Kumaraswamy, M. M. (2000). Improved subcontractor selection employing partnering principles. Journal of Management in Engineering, ASCE, 16, 47-57.

Yik, F., \& Lai, J. (2006). Problems with specialist subcontracting in the construction industry. ... Engineering Research and ..., 3, 183-194. Retrieved from http://bse.sagepub.com/content/27/3/183.short

Hinze, J. \& Tracey, A. (1994). The contractor-subcontractor relationship: the subcontractor's view. Journal of Construction Engineering and Management-ASCE, 120(2), 274-287.

Teng, B. S., \& Das, T. K. (2008). Governance structure choice in strategic alliances: The roles of alliance objectives, alliance management experience, and international partners. Management Decision, 46(5), 725-742.

Pratono, A. H., \& Ratih, R. V. (2019). International Alliance Strategies: A Case Study of the Indonesian Medical Device Industry. Globalization and Development, Contributions to Management Science, 381-400. doi:https://doi.org/10.1007/978-3-030-11766-5_15

Gammoh, B. S., \& Voss, K. E. (2013). Alliance competence: The moderating role of valence of alliance experience. European Journal of Marketing, 47(5/6), 964-986. 
Wong, A., Wei, L., \& Wang, X. (2018). Collectivist values for constructive conflict management in international joint venture effectiveness. International Journal of Conflict Management, 29(1), 126-143. 